\title{
THE INFLUENCE OF EMPLOYEE ENGAGEMENT AND JOB SATISFACTION ON ORGANIZATIONAL CITIZENSHIP BEHAVIORAT PT. RIZKI ASA BUANA
}

\author{
Imaduddin $\mathrm{Al}$ Azzam ${ }^{1}$ \\ ${ }^{1}$ Faculty of Economics, Universitas Negeri Jakarta \\ Jakarta, Indonesia \\ imad.kilz@gmail.com \\ Widya Parimita ${ }^{2}$ \\ ${ }^{2}$ Faculty of Economics, Universitas Negeri Jakarta \\ Jakarta, Indonesia \\ widya_parimita@unj.ac.id \\ Christian Wiradendi Wolor ${ }^{3}$ \\ ${ }^{3}$ Faculty of Economics, Universitas Negeri Jakarta \\ Jakarta, Indonesia \\ christianwiradendi@unj.ac.id
}

\begin{abstract}
The objectives of this study are: First, to find out the description of work engagement, job satisfaction and Organizational Citizenship Behavior (OCB) for employees of PT. Rizki Asa Buana, Second to determine the effect of Work Engagement on Organizational Citizenship Behavior (OCB) on employees of PT. Rizki Asa Buana, Third to determine the effect of Job Satisfaction on Organizational Citizenship Behavior (OCB) on employees of PT. Rizki Asa Buana. The Last is to find out how much the contribution of Job Engagement and Job Satisfaction to Organizational Citizenship Behavior (OCB) for employees of PT. Rizki Asa Buana. This research was conducted on 135 employees of PT. Rizki Asa Buana on Jl. Manggul jaya no.9 (base 4) cikiwul, bantar gebang. Bekasi 17152. The data collection technique used to survey and interview methods, namely by interviewing employees one by one and distributing questionnaires which were then processed using the SPSS program. This research uses descriptive and explanatory analysis. The results obtained from the regression show a positive and significant influence between Work Engagement on Organizational Citizenship Behavior and a positive and significant influence between Job Satisfaction
\end{abstract}


on Organizational Citizenship Behavior and the rese arch model of Job Engagement and Job Satisfaction can predict Organizational Citizenship Behavior in Pt. Rizki Asa Buana which is on Jl. Manggul jaya no.9 (base 4) cikiwul, bantar gebang. Bekasi 17152 with a value of Fcount $>$ Ftable $(62.091>2.70)$ and significance $(0.000<0.05)$.

Keyword: Employee Engagement, Job Satisfaction, Organizational Citizenship Behavior (OCB).

\section{INTRODUCTION}

Problems with low levels of OCB can occur in any company, including PT. Risky Asa Buana. Based on the data processed by the researcher, the researcher also conducted interviews with employees at PT. RAB. Regarding OCB, the employee explained that family gatherings in this company are rarely held, so that the closeness between employees is not good, and the desire to help each other between employees is still lacking. The employee complains that when the employee has permission or is sick, he feels that there is no one to help or handle the work. So that the work was done is not completed according to the deadline given by the company. This is also included in the OCB dimension, namely Altruism. Altruism is individuals who want to help other individuals in working in a company without compensation. Furthermore, as with Altruism, which supports OCB, there is a Conscientiousness dimension. Conscientiousness is the existence of an individual role in carrying out roles and tasks that should be carried out by other people in a company, according to (Podsakoff et al., 2005).

Researchers also obtained additional data related to OCB, namely data on resigning employees of PT. Riski Asa Buana interprets a form of employee intolerance towards the company that may be less than ideal for the employee, so the employee decides to resign. This is also inversely proportional to one of the OCB dimensions. This dimension is sportsmanship, and sportsmanship is the willingness to tolerate the inconveniences that often occur and the risks of work done without complaining, according to (Gautama 
Siregar, 2018). The following is the data of outgoing employees managed by the researcher:

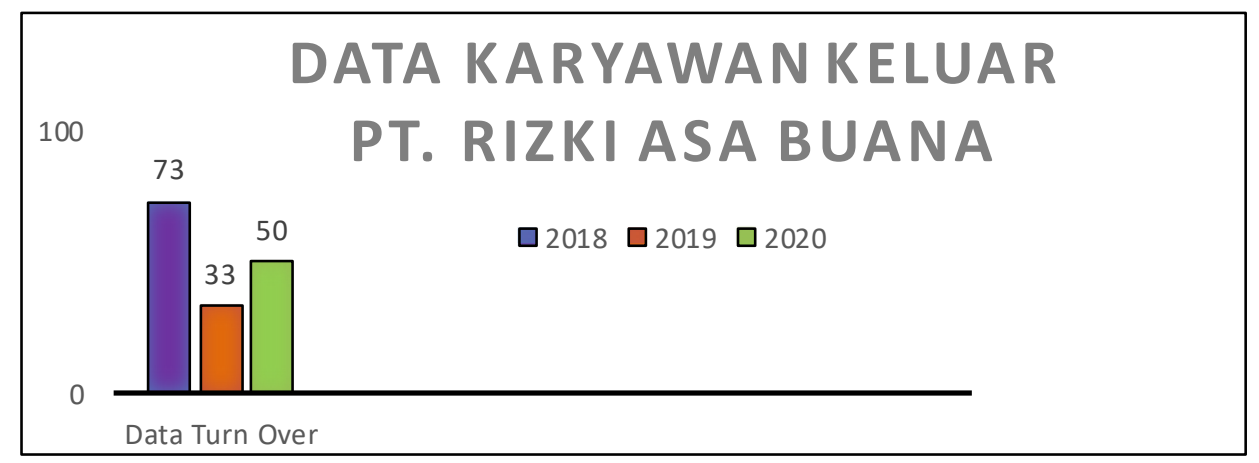

Figure 1. Data of employees leaving PT. Rizki Asa Buana

\section{Source: Processed by researchers}

Based on the data obtained by the researcher, several employees leave the company (figure 1). The picture shows that there are still employees who do not interpret the attitude of tolerance towards the company they are sheltering. The company is considered less than ideal and is still not in line with its vision and mission, thus contradicting one of the OCB dimension categories, namely sportsmanship.

Based on the understanding of sportsmanship that has been described above, it shows that the act of resigning by employees is a form of discomfort, resigning or turning over intention itself is an act of leaving an employee from a company that occurs because of the desire of the employee himself or a company that wants to issue it according to (Saeed et al., 2014). If employees have high sportsmanship, employees will continue to work for the company regardless of their complaints and will continue to make high contributions to the company.

Researchers also conducted interviews related to work engagement and job satisfaction. For work engagement, employees feel less enthusiastic in doing their work because the work given by the company is too heavy so that the work given by the company to the employee is neglected or completed outside the specified time because the employee does not have seriousness, enthusiasm, and persistence in doing work. This problem is in line with the dimensions of work engagement described by (Schaufeli et al., 2006), namely Vigor, Dedication and Absorption. 
Then the researchers conducted a pre-research test on 25 employees of PT. Rizki Asa Buana with a general description of the respondents consisting of 16 men and 9 women. 12 respondents were aged between 23-30 years, 8 respondents were aged 31-40 years, and 5 years respondents were aged 41-45 years. Furthermore, 20 respondents are permanent employees, and 5 respondents are contract employees by distributing questionnaires to company employees to determine why employees prefer to resign rather than stay in the company.

Based on the results of the pre-research questionnaire, it shows that the first variable, namely works engagement in the company, is still relatively low. This is indicated because employees still do not feel that they are tied to the company where they work. Work engagement itself is an essential dimension that can strengthen employee behaviour — oriented in achieving goals with high enthusiasm, enthusiasm, and pride in the work that is their profession now. As a result, employees will feel bound to their work and company, according to (Deviyanti \& Sasono, 2015). According to (Kataria et al., 2012), work engagement has the potential to encourage OCB. Similarly, according to (Ferdiansyah, 2018) Work engagement is a development of the two previous concepts, namely Commitment and OCB. Employees who do not give complete loyalty to the company, such as not enthusiastic about work, lack of desire to take the time to do work, and lack willingness to learn for the company's progress.

The second variable, namely job satisfaction, is still relatively low, below 50\%. Job satisfaction is an individual's assessment and attitude towards his work environment, type of work, relationships between co-workers, and social relationships that occur in the work environment (Tania \& Sutanto, 2013). Similarly, according to (Nkeobuna Nnah Ugoani, 2018), job satisfaction affects OCB with the most significant influence on the Pay dimension (salary). It is believed that salary can motivate behaviour and performance patterns, where it can be assumed that employees who havehigh salaries must have better performance and vice versa. Employees are rated as dissatisfied with their work and company policies. This dramatically affects the performance of employees, and employees become less enthusiastic in doing their jobs, less love for work and the company. Factors such as the lack of benefits provided by the company, the difficulty of 
getting promotions and the lack of good support among co-workers are triggers for the lack of job satisfaction within employees.

Job engagement and job satisfaction are two factors that support the creation of OCB (Organizational Citizenship Behavior). Employees who feel satisfied with their work will work optimally in completing their work, even willing to do work outside of their duties (Fauziridwan et al., 2018). Employees who have high engagement will show business behaviour by giving more time, effort, and initiative to their work and contributing to their organization (Affandi et al., 2019). Employees who feel satisfaction in their work and are bound by their work and the organizations they support will be willing to do more work than their supposed duties voluntarily without expecting rewards from the organization or company (willing to do OCB). Although the company tries to give the best to its employees, not a few employees still have obstacles to achieve job satisfaction and work engagement based on several factors that have been partially described above, so that OCB will be difficult to form in the company's employees.

To create OCB in each employee, what is needed is the existence of "job satisfaction and employee work engagement". Therefore, researchers are interested in researching the effect of Job Engagement and Job Satisfaction on OCB (Organizational Citizenship Behavior) on employees at PT. Rizki Asa Buana.

Furthermore, the researchers interviewed related to job satisfaction variables, where employees explained that they felt the salary they got from the company was not under the work they were doing. Then some employees have worked in the company for 5 to 10 years, but they did not get the promotion as expected. Furthermore, employees feel less guided by superiors, so that employees do not feel the closeness between superiors and subordinates. These problems are in line with the dimensions of job satisfaction described by Luthans (2006), namely Supervision, Promotion, Pay.

\section{LITERATURE REVIEW}

\section{Organizational Citizenship Behavior}

OCB, according to (Putri \& Utami, 2017) is a term for employees who give more value to the work that is their duty as well as an added value to the company, and the success of an organization is also supported by the behaviour of members in an organization or 
company. To create highly dedicated employees, companies must prioritize their employees to increase organizational effectiveness (Rohayati, 2014). Furthermore, this is supported by Kusdi (2011), who states that Organizational Citizenship Behavior (OCB) can be created, one of which is through organizational culture. Organizational Citizenship behaviour is the contribution of workers "above and above" a formal job description that is carried out voluntarily, which is not formally recognized by the reward system and contributes to the effectiveness and efficiency of organizational functions (Rohayati, 2014). Organizational Membership Behavior (OCB) is a personal contribution that goes beyond the requirements of a role in the workplace and is rewarded by obtaining task performance. OCB involves various behaviours, including volunteering to help others, performing additional tasks, and following workplace rules and procedures. This behaviour describes the added value of employees, which is a form of pro-social behaviour, namely positive social behaviour according to (Podsakoff et al., 2005).

Titisari (2014) defines Organizational Citizenship Behavior (OCB) as individual behaviour that is free, not directly or explicitly related to the reward system and can improve the effective functioning of the organization. Based on the experts' opinions above, the researcher synthesizes that OCB is a voluntary behaviour carried out by employees to help co-workers and the company and behaviour that is not part of the formal work obligations carried out by employees and plays a role in the success of the organization. In this study, researchers used the dimensions proposed by (Podsakoff et al., 2005), namely Altruism, Conscientiousness, Civic Virtue, Sportsmanship, Courtesy. These dimensions have also been carried out by several researchers, including (Tang \& Ibrahim, 1998), (Soegandhi et al., 2013) and (Ikonne, 2013).

\section{Employee Engagement}

According to (Bakker, A.B. \& Leiter, 2010), work engagement is a positive individual condition characterized by enthusiasm, dedication, and appreciation for work. At present, employees must also be willing to cooperate, aid, exchange suggestions, participate more and actively participate in the organization. To create these outstanding individuals, employees must maintain close relationships with the companies they protect to perform tasks other than their duties. This is the result of high loyalty to the company. Meanwhile, (Albrecht, 2010) suggests that work engagement is a state of positive motivation and 
energy related to work and the pure desire of employees to contribute to their work role and organizational success. Employees in an organization or company cannot be separated, and employees who excel and are innovative are the most supportive factors for the company's success or organization. Employees are expected not only to work by the given job descriptions but also to optimize their work.

Furthermore, according to (Djasa etal., 2020), work engagement is a favourable condition experienced by employees in their work and is indicated by the nature of the involvement of the workforce in carrying out their duties. Similarly, according to (Aldrin \& Merdiaty, 2019), work engagement is a positive and satisfying state of mind related to work characterized by enthusiasm, appreciation and dedication, emphasizing employees' insight into their work and, as a result, will increase creativity in the workplace. This means that work engagement can show a positive condition where employees feel the involvement of the workforce in carrying out their duties. According to (Schaufeli et al., 2006), work en gagement is a positive view of life, thinking about the unity of the working relationship, characterized by enthusiasm, high dedication, and appreciation. Moreover, (Solichin, 2018) states that if employees have a high sense of belonging to the organization, it will add three general behaviours that can improve organizational performance: the first to say (say) meaning that employees will give opinions to the organization and co-workers, as well as give opinions to employees. And potential customers. The second is that employees will continue to work in the organization even though they can work elsewhere. Moreover, third is the effort which means that employees will devote more time, energy, and initiative to the organization. From the above definition, the researcher synthesizes Job Engagement as an attitude or feeling attached to employees towards their organization that positively impacts the company, where employees are motivated to improve their performance in the company. In the work engagement variable, the researcher uses the dimensions of Vigor, Dedication, Absorption proposed by (Schaufeli et al., 2006) (Waspodo, 2019), (Chaudhary et al., 2017).

\section{Job Satisfaction}

According to Wibowo (2015), job satisfaction is the level of one's feelings of pleasure as a positive assessment of his work and the right work environment. Employees who are 
satisfied with what an organization or company provides to them and what they have done for the company will create a job satisfaction condition. If the employee already has job satisfaction, he will follow the work regularly, work hard, and remain an employee or member of the organization.

Meanwhile, according to Mangkunegara (2017) states that job satisfaction is a feeling that supports or does not support employees in their work and according to (Usman, 2011) states that job satisfaction is the fulfilment of all the needs of workers in carrying out their duties for a specific time. Job satisfaction is the assessment and attitude of an individual towards his work environment, type of work, relationships between co-workers, and social relationships in the work environment. Tania \& Sutanto (2013).

Another expert opinion, Robbins et al. (2011), states that job satisfaction is a positive feeling about one's job, which results from an evaluation of the individual's characteristics. Positive feelings of employees will also increase the level of job satisfaction. Otherwise, negative feelings of employees will decrease or even eliminate job satisfaction. According to (Asrunputri, 2018) job satisfaction is the behaviour of someone who has an emotional response to his work.

On the Job Satisfaction variable, researchers used the dimensions of work, supervisor, promotion, co-workers, and salary. This dimension has also been used by Luthans (2006), (Puspitawati \& Riana, 2014), (Smith, 2017), (Kerdngern \& Thanitbenjasith, 2017).

Based on the explanation above, the researcher concludes that job satisfaction can be created when there is no longer a difference between what is desired and its perception with the existing reality because the desired minimum limit has been achieved or fulfilled. In other words, job satisfaction also shows the level of individual expectations of the person's psychological fulfilment.

\section{Conceptual Framework}

H1: Employee engagement affects organizational citizenship behaviour (OCB)

Research conducted by Solichin (2018) states that employee engagement significantly affects organizational citizenship behaviour. Then the research conducted by Kasinathan et al. (2016) also stated that employee engagement has a significant effect on organizational citizenship behaviour. However, the research conducted by Affandi et al. 
(2019) showed that employee engagement did not have a significant effect on organizational citizenship behaviour.

$\mathrm{H} 2$ : Job satisfaction affects organizational citizenship behaviour (OCB)

Research conducted by Saxena et al. (2018) states that job satisfaction significantly affects organizational citizenship behaviour. The research conducted by Waspodo (2019) also states that job satisfaction significantly affects organizational citizenship behaviour. However, Ningsih et al. (2014) research state that job satisfaction has no significant effect on organizational citizenship behaviour.

H3: Employee engagement and job satisfaction affects organizational citizenship behaviour (OCB)

Research conducted by Claudia et al. (2013) and Rohayati (2014) shows that employee engagement and job satisfaction have a significant influence on organizational citizen ship behaviour (OCB). However, research conducted by Affandi et al. (2019) and Ningsih et al. (2014) shows that employee engagement and job satisfaction do not have a significant effect on organizational citizenship behaviour (OCB).

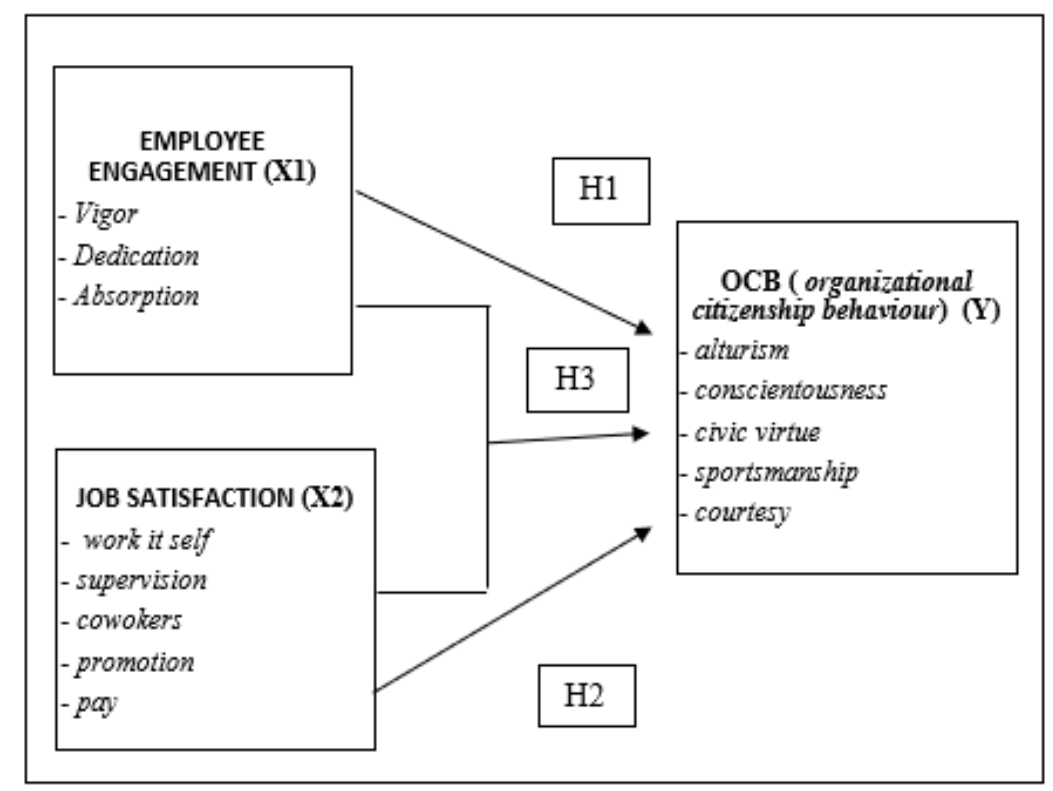

Figure 2. Research Model

Source: Processed by researchers 


\section{RESEARCH METHOD}

According to Gujarati (2011) in Setyawan et al. (2020), the population is the set of all possible results attributed to an experiment. The population in this study are all employees, amounting to 135 people who work at PT. Rizki Asa Buana. According to Sekaran \& Bougie (2009), a Sample is part of the number and characteristics possessed by the population. Moreover, the researchers used non-probability sampling. Non-probability sampling is a sampling technique that does not provide equal opportunities or opportunities for each element or member of the population to be selected as a sample. This sampling technique includes systematic, quota, accidental, purposive, saturated and snowball sampling.

In this study, there are 45 indicators/statements. Data analysis in this study used the SPSS version 22 program. The measurement scale in this study used a Likert scale. The Likert scale, according to Sekaran \& Bougie (2009), is designed to examine how strongly the subject agrees or disagrees with questions on a four-point scale. With a Likert scale, the variables to be measured are translated into indicator variables. These indicators are used as a starting pointfor compiling instrument items in statements or questions. In this study, we will use a Likert scale with an interval of 1 to 4, referring to Sugiyono (2015), which states where it is deemed more appropriate and following the circumstances because if using an interval of 1 to 5 , the results of the study are feared to be biased because most respondents will choose a neutral answer so that it is difficult to draw conclusions as well as judgments from these criteria. If the direction of the assessment is getting to the right, it shows the "Strongly Agree" opinion, which means it is getting stronger. If the direction of the assessment is further to the left, it indicates a "Strongly Disagree" opinion, which means it is getting weaker.

Sekaran \& Bougie (2009) stated that Primary Data refers to information obtained directly by researchers about variables of interest for specific research purposes. In collecting primary data, the researcher used a survey method using a questionnaire distributed to respondents. 


\section{RESULT AND DISCUSSION}

\section{Descriptive Analysis}

\section{Organizational Citizenship Behavior}

Overall, compared with the weight of the variable criteria scores, the number of strongly disagree and disagree answers given by the respondents is $93.7 \%$, meaning that the OCB variable is deficient. Based on these results, there is a very low OCB in employees in the company. This result is supported by the Civic Virtue dimension, where the indicators of reading and hearing announcements and memos conveyed by coworkers can be concluded that employees feel they do not read and hear announcements and memos conveyed by coworkers. Things like this can be detrimental to the company if it continues. Therefore, more attention is needed from the company to read and listen to announcements and memos conveyed by colleagues.

\section{Employee Engagement}

Overall, compared with the variable criteria scores, the number of answers disagreeing and strongly disagreeing given by the respondents is $60.6 \%$, meaning that the Job Engagement variable is low. Based on these results, there is low work engagement among employees in the company. This result is also supported by the Absorption dimension, where on the indicators of focus at work, it can be concluded that there are employees who feel unfocused at work. Things like this can be detrimental to the company if it continues. Therefore, there needs to be more attention from the company to feel focused and live in doing their work.

\section{Job Satisfaction}

Overall, compared with the weight of the variable criteria scores, the number of answers disagreeing and strongly disagreeing given by the respondents is $92.4 \%$, which means that job satisfaction is deficient. This is also supported by the dimension of work with the highest indicator, namely being satisfied with the job. It can be concluded that employees are not satisfied with their work. Things like this can be detrimental to the company if it continues. Therefore, more attention is needed from the company so that employees feel satisfied in doing their jobs. 


\section{Multiple Linear Regression Test Results}

\section{T test results}

Table 1. Multiple Linear Regression Test Results Coefficients $^{\mathrm{a}}$

\begin{tabular}{|c|c|c|c|c|c|}
\hline \multirow[b]{2}{*}{ Model } & \multicolumn{2}{|c|}{$\begin{array}{l}\text { Unstandardized } \\
\text { Coefficients }\end{array}$} & \multirow{2}{*}{$\begin{array}{c}\text { Standardized } \\
\text { Coefficients } \\
\text { Beta }\end{array}$} & \multirow[b]{2}{*}{$\mathrm{t}$} & \multirow[b]{2}{*}{ Sig. } \\
\hline & B & $\begin{array}{l}\text { Std. } \\
\text { Error }\end{array}$ & & & \\
\hline (Constant) & 4,954 & 2,453 & & 2,020 &, 045 \\
\hline $\begin{array}{c}\text { Employee } \\
\text { Engagement }\end{array}$ & ,491 & ,064 &, 506 & 7,712 & ,000 \\
\hline $\begin{array}{c}\text { Job } \\
\text { Satisfaction }\end{array}$ &, 425 & ,080 & ,348 & 5,295 & , 000 \\
\hline
\end{tabular}

a. Dependent Variable: OCB

\section{Source: Processed by researchers}

The formulation of the hypothesis and the decision-making criteria are:

Formulation of Hypothesis $1(\mathrm{H} 1)$

Hypothesis 1:

Ho: Work engagement does not have a positive effect on Organizational Citizenship Behavior

Ha: Work engagement has a positive effect on Organizational Citizenship Behavior Formulation of Hypothesis $2(\mathrm{H} 2)$

Hypothesis 2:

Ho: Job Satisfaction has no positive effect on Organizational Citizenship Behavior Ha: Job Satisfaction has a positive effect on Organizational Citizenship Behavior The basis of decision making is to compare $t$ count with $t$ table as follows:

The work engagement variable has a t-value of 7.712. The tcount value of the work engagement variable was then compared with the ttable value. Thus, $t$ count $>t$ table is $7,712>1,997$. The significance of the work engagement variable is 0.000 and less than 0.05. So the conclusion drawn is that Ho is rejected and Ha is accepted. Thus, work engagement has a positive effect on Organizational Citizenship Behavior.

Job Satisfaction variable has a t count of 5.295. The t count value of the Job Satisfaction variable is then compared with the $t$ table value. Thus, $t$ count $>t$ table is $5.295>1.997$. The significance of the Job Satisfaction variable is 0.000 and less than 0.05 . So the 
conclusion drawn is that Ho is rejected and $\mathrm{Ha}$ is accepted. Thus Job Satisfaction has a positive effect on Organizational Citizenship Behavior.

\section{Multiple Linear Regression Test Results}

Based on Table 1, the linear regression equation obtained is $\mathrm{Y}=4.954+0.491 \mathrm{X} 1+$ $0.425 \mathrm{X} 2$. The meaning of the figures in the above equation is as follows:

1. The regression coefficient value of the work engagement variable is positive, namely 0.491 . This means that for every one increase in work engagement score, it will increase Organizational Citizenship Behavior by 0.491 scores with a fixed Job Satisfaction variable.

2. The regression coefficient value of the Job Satisfaction variable is positive, namely 0.425 . This can be interpreted that every one increase in Job Satisfaction score will increase OrganizationalCitizenship Behavior by 0.425 .

\section{F Test Results}

$F$ test needs to be done to test whether there is an effect between job engagement and job satisfaction or simultaneously on Organizational Citizenship Behavior. Decision making criteria:

Ho: The independent variables of job engagement and job satisfaction cannot predict the model on the dependent variable of Organizational Citizenship Behavior.

Ha: The independent variables of job engagement and job satisfaction can predict the model on the dependent variable of Organizational Citizenship Behavior.

Based on F test:

1. Ho is accepted if F count $<F$ table

2. Ho is rejected if F count $>\mathrm{F}$ table

By significance:

1. Ho is accepted if the significance $>0.05$

2. Ho is rejected if the significance is $<0.05$ 
The results of the F test can be seen in table 2 below:

Table 2.F Test Results

\begin{tabular}{|c|c|c|c|c|c|c|}
\hline \multicolumn{7}{|c|}{ ANOVA $^{a}$} \\
\hline \multicolumn{2}{|c|}{ Model } & $\begin{array}{c}\text { Sum of } \\
\text { Squares }\end{array}$ & $\mathrm{df}$ & $\begin{array}{c}\text { Mean } \\
\text { Square }\end{array}$ & $\mathrm{F}$ & Sig. \\
\hline 1 & Regression & 1800,982 & 2 & 900,491 & 62,091 &, $000^{\mathrm{b}}$ \\
\hline & Residual & 1914,351 & 132 & 14,503 & & \\
\hline & Total & 3715,333 & 134 & & & \\
\hline
\end{tabular}

Source: Processed by researchers

In Table 2, the Fcount obtained is 62,091. The Fcount value is then compared with the Ftable value, which is searched with a $95 \%$ confidence level, with df 1 (number of variables-1) or 3-1 =2, and df 2 (n-k-1) or 135-2-1. Based on these calculations, obtained Ftable of 2.70, thus Fcount> Ftable. The significance of the F test is 0.000 ; thus smaller than 0.05 . The conclusion that can be drawn is that Ho is rejected or the independent variables of job engagement and job satisfaction can predict the model on the dependent variable of Organizational Citizenship Behavior.

\section{Coefficient of Determination Test Results (R2)}

Table 3. Coefficient of Determination Test Results Model Summary ${ }^{\mathrm{b}}$

\begin{tabular}{ll|l|l|l|l} 
Model & $\mathrm{R}$ & R Square & $\begin{array}{c}\text { Adjusted } \\
\text { Square }\end{array}$ & $\begin{array}{c}\text { Std. Error of the } \\
\text { Estimate }\end{array}$ \\
\hline 1 &, $696^{\mathrm{a}}$ &, 485 &, 477 & 3,808
\end{tabular}

a. Predictors: (Constant), Kepuasan Kerja, Keterikatan Kerja

b. Dependent Variable: OCB

\section{Source: Processed by researchers}

Based on the table, the value of R2 (R square) is 0.485 or $(48.5 \%$ ). This shows that $48.5 \%$ of Organizational Citizenship Behavior is explained by Job Engagement and Job Satisfaction factors, while the remaining $51.5 \%$ is explained by other variables. 


\section{CONCLUSION}

Description of Job Engagement, Job Satisfaction and Organizational Citizenship Behavior on employees of Pt. Rizki Asa Buana: Work Engagement on employees at Pt. Rizki Asa Buana is classified as low, which means that many employees do not feel attached to the job. This conclusion is derived from the three largest dimensions of influence in the study: First, the Absorption dimension, where on the indicator of focus in working with statements, I am immersed in this work. The two dimensions of Dedication are the indicators of Challenges at work with the statement I am happy to be challenged in doing this work. The three dimensions of Vigor are Resilience indicators in working with the statement I have high work resistance. Based on the three dimensions above, it can be concluded that the presence of employees whofeel unfocused at work is the most significant influence on the Job Engagement variable. Things like this can be detrimental to the company if it continues. Therefore, there needs to be more attention from the company to feel focused and live in doing their work.

Job Satisfaction on employees at Pt. Rizki Asa Buana is still relatively low, which means that many employees are not satisfied with their work. This conclusion was obtained from the three largest dimensions of influence in the study: First, the dimension of work with indicators, namely feeling satisfied with the work with the statement that I was satisfied with the task. Both Coworkers with indicators Relationships with coworkers are going well with statements. Relationships with coworkers are well established, the three dimensions of superiors with indicators. Communication between subordinates and superiors is going well with statements. Communication between superiors and subordinates is well established in solving work problems. Based on the three dimensions above, it can be concluded that employees feel dissatisfied with their work to be the most significant influence on the Job Satisfaction variable. Things like this can be detrimental to the company if it continues. Therefore, there needs to be more attention from the company to feel satisfied in doing their jobs.

Organizational Citizenship Behavior on employees of PT. Rizki Asa Buana is still classified as low, which means that many employees do not have the initiative and high awareness of work. This conclusion is derived from the three most prominent dimensional 
influences in the study: First, the Civic Virtue dimension on the indicator Reading and paying attention to organizational announcements, memos, and the like with statements Always reading and listening to announcements and memos conveyed by my colleagues. Both Sportsmanship on indicators Always focuses on the positives rather than the negatives about your company with a statement, and I will take the positive side of the problem that occurs. The third is the Conscientiousness dimension on the indicator Working beyond the specified working hours with the statement I am willing to come to the office before work hours. Based on the three dimensions above, it can be concluded that employees feel they do not read and hear announcements and memos conveyed by coworkers to be the most significant influence on the OCB variable. Things like this can be detrimental to the company if it continues. Therefore more attention is needed from the company to read and listen to announcements and memos conveyed by colleagues. Job Engagement has a positive effect on OCB for Pt employees. Rizki Asa Buana. This means that when the employee's work engagement increases, the employee's OCB will increase. Job Satisfaction has a positive effect on the OCB of Pt employees. Rizki Asa Buana, which means that if job satisfaction increases, employee OCB will increase. Model penelitian Kepuasan Kerja dan Keterikatan Kerja dapat memprediksi OCB pada karyawan di Pt. Rizki Asa Buana.

Work engagement (X1). Descriptively, most respondents responded negatively to statements about work-relatedness. From this negative response, one of the steps that can be taken is to increase employee work engagement by generating high morale and work power for employees, increasing employee seriousness to work, and the desire to continue to find solutions to every problem and difficulty that employees face. Based on the study results, the best dimension that the company has is Vigor; that is, employees already have enthusiasm and have high work desire. So this can make employees have a high sense of attachment to the job. It is expected that the company can improve and maintain these dimensions.

Job Satisfaction (X2) descriptively, most respondents responded negatively to the statement that the researcher proposed to the employees. In order to improve Organizational Citizenship Behavior, the management of PT Rizki Asa Buana should direct employees to the work they are responsible for, build good communication, provide 
equal opportunities for all employees for promotion, provide salaries that are by the minimum wage and meet the needs of employees and build solid teamwork among employees. Based on this research, the best dimension that the company has is promotion; this means that the company must be able to increase and maintain the promotion of employees so that employees can feel satisfied in their work.

In the OCB variable in the statement, feeling reading and hearing announcements and memos conveyed by colleagues is the highest percentage (STS + TS). This means that employees feel they do not read and hear announcements and memos conveyed by coworkers. For this reason, it is necessary to make a breakthrough or innovation when giving memos to colleagues through other media, not with another piece of paper but through social media that is used by all employees so that it is more effective. Considering that all employees use social media.

In the work engagement variable in the statement, I am involved in this job, which is the highest percentage (STS+TS). This indicates if the employee is not involved with the work he is doing. This indicates that employees have less engagement with the work they do. For this reason, the management should be able to generate high morale and workforce for employees, increase the seriousness of employees to work, and the desire to continue to find solutions to every problem and difficulty that employees face. On the job satisfaction variable in the statement, I feel satisfied with the task given, which is the highest percentage (STS+TS). This indicates if the employee is not satisfied with the assigned task. This indicates that the employee is assigned or assigned a position or job that is not his/her field or educational background. For this reason, management needs to evaluate when giving a job to its employees so that employees work according to their educational background.

Here is some suggestion for further research:

1. Regarding the limitations of research carried out during the Covid-19 pandemic, the lack of information obtained by the researcher is hoped to find more information related to the problems that occur in future studies.

2. This research can be done again with free and independent variables in different places/research objects or using other variables in accordance with the problems that occur in the object of research. 


\section{References}

Affandi, A. S., Patrisia, D., Syahrizal, S., \& Abror, A. (2019). The Effect of Employee Engagement and Job satisfaction on Organizational Citizenship Behavior (OCB). (May). https://doi.org/10.2991/piceeba2-18.2019.69.

Albrecht, S. L. (2010). Handbookofemployee engagement: Perspectives, issues, research and practice. Cheltenham: Edward Elga .

Aldrin, N., \& Merdiaty, N. (2019). Effect of job crafting on work engagement with mindfulness as a mediator. Cogent Psychology, 1-14.

Asrunputri, A. P. (2018). Pengaruh Kepuasan Kerja, Keterlibatan Kerja, dan Perceived Organizational Support Terhadap Komitmen Organisasional Pada Bank Syariah Mandiri. Jurnal Dinamika Manajemen Dan Bisnis, 1(2), 1-17. https://doi.org/10.21009/jdmb.01.2.01.

Bakker, A.B. \& Leiter, M.P. (2010). Work Engagement: A handbook of essential theory and research. New York: Psychology Press.

Bolino, M. C., Turnley, W. H., Bloodgood, J. M., \& Bolino, M. C. (2009). And the creation Citizenship of Social capital in organizations. 27(4), 505-522.

Chaudary, R., dkk. (2017) Work Engagement in India and Thailand: Acomparative analysis. Global Bussiness Review, 19(1), 1-13.

Claudia, V., Putri, K., Indriati, F., Liestiawati, D., \& Si, M. (2013). Pengaruh Employee Egangement terhadap Organizational Citizenship Behavior pada karyawan Kantor pusat PT. Sepatu Bata, TBK.

Deviyanti, A. D., \& Sasono, A. D. (2015). Pengaruh Sumber Daya Pekerjaan (Job Resources) Dengan Keterikatan Kerja (Work Engagement) Sebagai Mediator Terhadap Perilaku Proaktif (Studi Pada Karyawan Pt Rga International Indonesia). E-Journal Ilmu Manajemen MAGISTRA, 1(1), 16-30.

Djasa, K., Suyasa, P. T. Y. S., \& Hutapea, B. (2020). Peran Keterikatan Kerja Sebagai Mediator Efikasi Diri Dalam Memprediksi Intensi Kerja. Jurnal Muara Ilmu Sosial, $\begin{array}{llll}\text { Humaniora, } & \text { Dan } & \text { Seni, } & 4(1),\end{array}$ https://doi.org/10.24912/jmishumsen.v4i1.7564.2020. 
Fauziridwan, M., Adawiyah, W. R., \& Ahmad, A. A. (2018). Pengaruh Employee Engagement Dan Kepuasan Kerja Terhadap Organizational Citizrnship Behavior (OCB) Serta Dampaknya Terhadap Turnover Intention. Jurnal Ekonomi, Bisnis Dan Akuntansi, 20(1), 1-23.

Ferdiansyah, M. (2018). Analisis Pengaruh Gaya Kepemimpinan Transformasional, Kompensasi dan Program Pelatihan terhadap Employee Engagement serta Dampaknya terhadap Kinerja Karyawan di PT. Angkasa Pura II. Photosynthetica, 2(1), 1-13.

Gautama Siregar, B. (2018). Organizational Citizenship Behavior Dan Kinerja Akademis Mahasiswa. FITRAH: Jurnal Kajian Ilmu-Ilmu Keislaman, 4(1), 29. https://doi.org/10.24952/fitrah.v4i1.874.

Hendrawan Andi, Sucahyawati Hari, I. (2015). Organizational Citizenship Behavior (OCB) pada karyawan Akademi Maritim Nusantara. Staf Pengajar Aakademi Maritim Nusantara, Cilacap. 39-48.

Ikonne, C. N. (2013). Job Satisfaction and Organizational Citizenship Behavior of Library Personnel in Selected Nigerian Universities. International Journal of Science and Research (IJSR) ISSN (Online Index Copernicus Value Impact Factor, 14(4), 2319-7064. www.ijsr.net.

Imam Ghozali. (2011). Aplikasi Analisis Multivariate dengan Program IBM SPSS 19. Semarang: Badan Penerbit Universitas Diponegoro.

Indrasari, Meithiana. (2017). Kepuasan Kerja dan Kinerja Karyawan (tinjauan dari dimensi iklim organisasi, kreativitas individu dan karakteristik pekerjaan). Indomedia Pustaka, Sidoarjo.

Kasinathan, S., \& Mohanty, R. (2016). Impact of employee engagement on organizational citizenship behavior: An overview. Espacios, 40(7).

Kataria, A., Garg, P., \& Rastogi, R. (2012). “Employee Engagement and Organizational Effectiveness: The Role of Refer Organi z a tiona l Citi z enship Behavior." International Journal of Business Insights \& Transformation, 6(1), 102-113.

Kerdngern, N., \& Thanitbenjasith, P. (2017). Influence of contemporaryleadership on job satisfaction, organizational commitment, and turnover intention: A case study of the 
construction industry in Thailand. International Journal of Engineering Business Management, 9, 1-8. https://doi.org/10.1177/1847979017723173.

Kusdi. (2011). Budaya Organisasi Teori, Penelitian, dan Praktik. Jakarta: Salemba Empat. Luthans, Fred. (2006) Perilaku organisasi, edisi sepuluh, Yogyakarta: Penerbit ANDI. Ma'ruf Abdullah. (2015). Metode Penelitian Kuantiatif. Yogyakarta: Aswaja Pressindo. MacKenzie, S. B., Podsakoff, P. M., \& Jarvis, C. B. (2005). The problem of measurement model misspecification in behavioral and organizational research and some recommended solutions. Journal of Applied Psychology, 90(4), 710-730. https://doi.org/10.1037/0021-9010.90.4.710.

Mangkunegara, A. A. (2017). Manajemen Sumber Daya Manusia Perusahaan. Bandung: PT Remaja Rosdakarya.

Merekrut, D., Baru, K., Bank, D. I., \& Cabang, M. (2016). Journal of Management Vol.2 No.2, Maret 2016.2(2).

Nafi', C \& Indrawati, S. (2017). Hubungan Antara Kepuasan Kerja Dengan Organizational Citizenship Behavior Pada. Jurnal Empati, 7(Nomor 3), 134-145.

Ningsih, F. rida, \& Arsanti, T. ari. (2014). Pengaruh Job Satisfaction terhadap OCB dan Turnover Intention. Benefit Jurnal Manajemen Dan Bisnis, 18(1), 41-48.

Nkeobuna Nnah Ugoani, J. (2018). Influence of Job Satisfaction on Organizational Citizenship Behavior in Nigeria. 3(4), 81. https://doi.org/10.5220/0007115200870091.

Prihantoro. (2012) Peningkatan Kinerja Sumber DayaManusia Melalui Motivasi, Disiplin, Lingkungan Kerja dan Komitmen. Studi kasus madrasah di lingkungan yayasan salafiyah, Pati.

Priyatno, Duwi. (2010). Paham Analisa Statistika Data dengan SPSS. Cetakan pertama. Yogyakarta: Media Kom.

Puspita, M. D. (2012). Hubungan antara Dukungan Sosial dan Makna Kerja Sebagai Panggilan (Calling) dengan Keterikatan Kerja. Calyptra: Jurnal Ilmiah Mahasiswa Universitas Surabaya, 1(1), 1-17.

Puspitawati, Dwi made ni, \& Riana, gede i. (2014). Pengaruh Kepuasan Kerja Terhadap Komitmen OrganisasionalDan Kualitas Layanan. Jurnal Manajemen, Strategi Bisnis Dan Kewirausahaan, 8(1), 68-80. 
Putri, Y., \& Utami, H. (2017). Pengaruh Organizational Citizenship Behavior (OCB) terhadap kinerja Studi Pada Tenaga Perawat Ruang Rawat Inap Rumah Sakit Baptis Batu. Jurnal Administrasi Bisnis S1 Universitas Brawijaya, 46(1), 27-34.

Robbins, S.P., and judge, T.A. (2011) perilaku organisasi, salemba empat, Jakarta.

Rohayati, A. (2014). Pengaruh Kepuasan Kerja Terhadap Organizational Citizenship Behavior: Studi Pada Yayasan Masyarakat Madani Indonesia. Jurnal Study \& Management Research STIE STEMBI Bandung Business School, XI(1), 20-38. https://doi.org/ISSN: 1693-4474.

Saeed, I., Waseem, M., Sikander, S., \& Rizwan, M. (2016). The relationship of Turnover intention with job satisfaction, job performance, Leader member exchange, Emotional intelligence and organizational commitment. 4(2). https://doi.org/10.5296.

Saxena, S., Tomar, K., \& Tomar, S. (2018). Impact of Job Satisfaction on Organizational Citizenship Behavior. 1994,87-91.https://doi.org/10.5220/0007115200870091 .

Schaufeli, W. B., Bakker, A. B., \& Salanova, M. (2006). The measurement of work engagement with a short questionnaire: A cross-national study. Educational and Psychological Measurement, 66(4), 701-716. https://doi.org/10.1177/0013164405282471.

Schnake, M. E., \& Dumler, M. P. (2003). Levels of measurement and analysis issues in organizational citizenship behaviour research. Journal of Occupational and Organizational Psychology, 76(3), 283-301.

Sekaran, U., \& Bougie, R. (2009). Research Methods for Business A Skill Building Approach. Research Methods for Business. http://www.ghbook.ir/index.php.

Smith, J. G. (2017). The Narcissistic Salesperson: A Framework of Their Relationships with Job Satisfaction, Organizational Commitment, and Customer Orientation. Atlantic Marketing Journal, 6(2), 1-21.

Soegandhi, V. M., Sutanto, E. M., \& Setiawan, R. (2013). Pengaruh Kepuasan Kerja dan Loyalitas Kerja Terhadap Organizational Citizenship Behavior Pada Karyawan PT Surya Timur Sakti Jatim. Volume 1. Nomor 1. Program Manajemen Bisnis, Program Studi Manajemen. Universitas Kristen Petra. Jurnal AGORA, 1(1).

Solichin, M. R. (2018). Analisis Pengaruh Employee Engagement, Emotional Intelligenc, dan Komitmen terhadap Organizational Citizenship Behavior (OCB) pada 
Karyawan PO Efisiensi Cabang Kebumen Much. Riyadus Solichin Program Studi Manajemen, STIE Putra Bangsa Kebumen. Jurnal Ekonomi Dan Teknik Informatika STIE Putra Bangsa, 6(2), 36-47. https://doi.org/ISSN: 2338-4697, e-ISSN: 25793322.

Sridhar, A., \& Thiruvenkadam, T. (2014). Impact of employee engagement on organization citizenship behaviour. Journal of Management Research2, 6(2), 147$155 . \quad \mathrm{http}: / / \mathrm{www}$. achievers.com/system/files/resource/analyst-insightsHBR_Achievers

Sugiyono. (2015). Metode Penelitian Kombinasi (Mix Methods).

Sugiyono. (2015). Metode Penelitian Bisnis. Bandung: CV. Alfabeta.

Tang, T. L. P., \& Ibrahim, A. H. S. (1998). Antecedents of organizational citizenship behavior revisited: Public personnel in the United States and in the Middle East. Public Personnel Management, 27(4), 529-549. https://doi.org/10.1177/009102609802700407.

Tania, A., \& Sutanto, E. M. (2013). Pengaruh Motivasi Kerja Dan Kepuasan Kerja Terhadap Komitmen Organisasional Karyawan Pt . Dai Knife Di Surabaya. 1(3).

Titisari, purnamie. (2014). Peranan organizational citizenship behavior (OCB) dalam meningkatkan kinerja karyawan. Mitra Wacana Media, Jember.

Usman, H. (2011). Manajemen. Jakarta: Bumi Aksara.

Waspodo, A. (2019). Pengaruh Kepuasan Kerja dan Lingkungan Kerja Terhadap Organizational Citizenship Behavior Karyawan Perum Damri Kantor Pusat. Journal of Chemical Information and Modeling, 10(1), 1689-1699.

Wibowo. (2015). Perilaku dalam Organisasi. Jakarta: PT Raja Grafindo Persada.

Wiwik Susilowati, E. W. (2010). Pengaruh Kepemimpinan, Organizational Citizenship Behaviour, dan Komitmen Organisasional terhadap Kepuasan Kerja Pegawai. Jurnal Ekonomi Dan Kewirausahaan, 10(1), 23423.

Wolo, P. D., Trisnawati, R., \& Wiyadi. (2015). Faktor Faktor Yang Mempengaruhi Kepuasan Kerja Perawat Pada RSUD TNI AU Yogyakarta. Jurnal Ekonomi Manajemen Sumber Daya, 17, 25-34. 


\section{Appendix}

\section{Questionnaire Table}

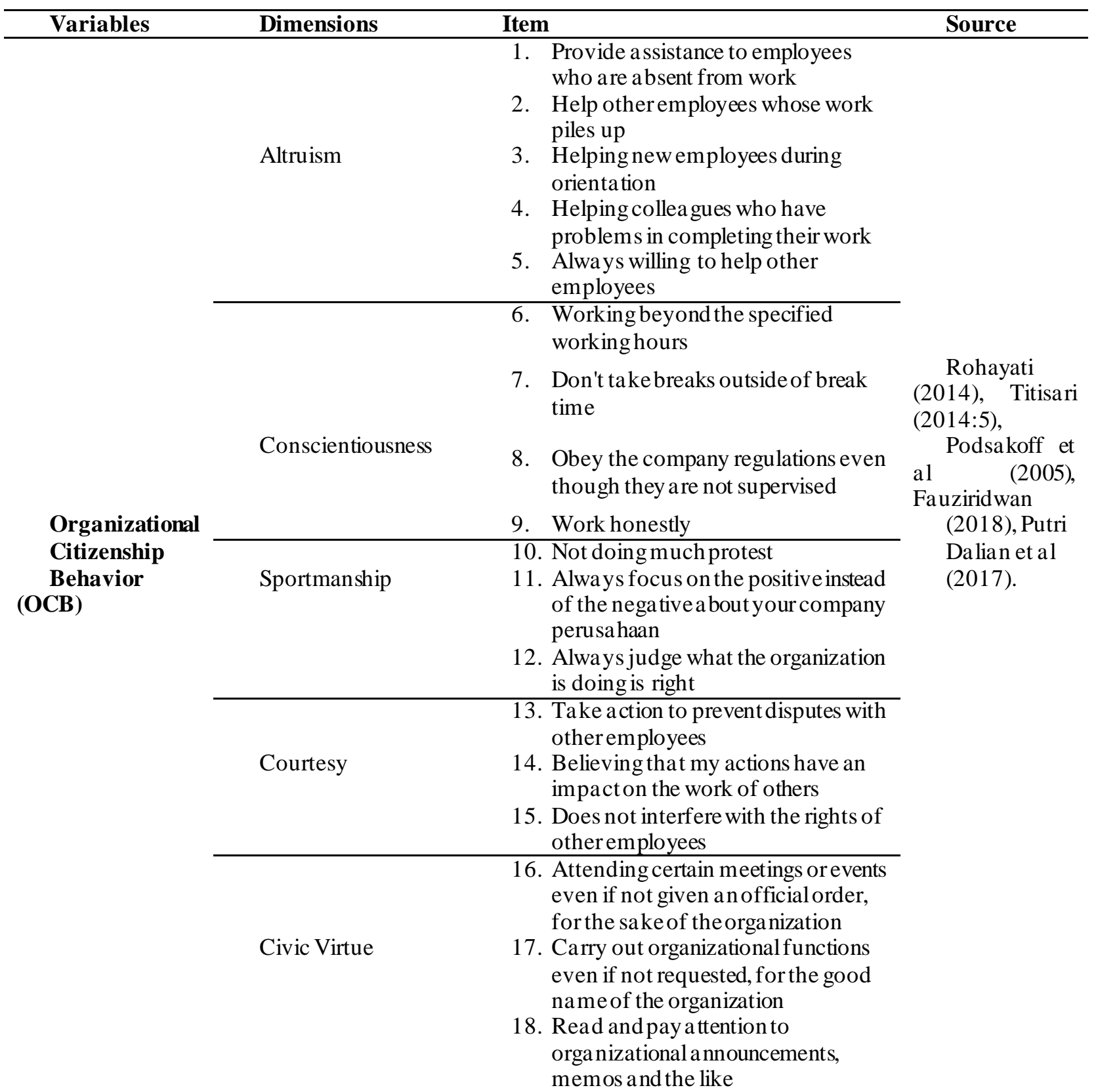

19. Strong a nd passionate at work

20. Very energetic at work

Vigor 21. Always feeling excited

22. long working time

23. Endurance at work

24. Never give up

25. Meaning in work

Schaufeli et al

26. Enthusiasm at work

Employee

Dedication
(2006),

Solichin

(2018), 


\begin{tabular}{|c|c|c|c|}
\hline Variables & Dimensions & Item & Source \\
\hline \multirow[t]{6}{*}{ Engagement } & & 28. Proud of work & \multirow{6}{*}{$\begin{array}{l}\text { Kurniawati } \\
\text { (2014) } \\
\text {, Kiransa Putri } \\
\text { et al(2013), } \\
\text { Fauziridwan } \\
\text { (2018). }\end{array}$} \\
\hline & & 29. Cha llenges at work & \\
\hline & \multirow{4}{*}{ Absorption } & 30. Comfortat work & \\
\hline & & $\begin{array}{l}\text { 31. Happy with busy work } \\
\text { 32. Focus on work }\end{array}$ & \\
\hline & & 33. Atmosphere at work & \\
\hline & & 34. Find it difficult to give up work & \\
\hline Variables & Dimensions & Item & Source \\
\hline \multirow{11}{*}{$\begin{array}{c}\text { Job } \\
\text { Satisfaction }\end{array}$} & \multirow{3}{*}{ Work } & 35. Do a good job & \multirow{11}{*}{$\begin{array}{l}\text { Tania dan } \\
\text { Sutanto } \\
\quad(2013), \\
\text { Robins } \\
\text { et al (2011), } \\
\text { Indrasari } \\
\text { (2017:42), } \\
\text { Rohayati } \\
\text { (2014), Alwan }\end{array}$} \\
\hline & & 36. Feeling sa tisfied with work & \\
\hline & & $\begin{array}{l}\text { 37. Doing work according to my } \\
\text { background }\end{array}$ & \\
\hline & \multirow[t]{2}{*}{ Ma nager/Supervisor } & $\begin{array}{l}\text { 38. The ma nager a lways gives } \\
\text { guida ance }\end{array}$ & \\
\hline & & $\begin{array}{l}\text { 39. Good communication between } \\
\text { subordinates and superiors }\end{array}$ & \\
\hline & \multirow[t]{3}{*}{ Promotion } & 40. There is an opportunity for & \\
\hline & & promotion & \\
\hline & & $\begin{array}{l}\text { 41. The existence of a promotion has a } \\
\text { positive impact on work }\end{array}$ & \\
\hline & \multirow[t]{2}{*}{ Wages } & 42. Ba sic sa lary is in accordance with & \\
\hline & & $\begin{array}{l}\text { 43. I am satisfied with the sa lary at the } \\
\text { company }\end{array}$ & \\
\hline & Work colleague & $\begin{array}{l}\text { 44. Good relationship with co-workers } \\
\text { 45. Receive support from co-workers }\end{array}$ & \\
\hline
\end{tabular}

